\title{
Livelihood Diversification and Sustainability of Rural Non-Farm Enterprises in Ghana
}

\author{
Joseph K. Assan ${ }^{1}$ \\ ${ }^{1}$ Center for Global Development and Sustainability, Heller School for Social Policy and Management, Brandeis \\ University, MA, USA \\ Correspondence: Joseph K. Assan, Center for Global Development and Sustainability, Heller School for Social \\ Policy and Management, Brandeis University, 415 South Street, MS 035, Waltham, MA, 20454. USA. E-mail: \\ joeassan@brandeis.edu
}

Received: July 11, $2014 \quad$ Accepted: July 29, 2014 Online Published: November 26, 2014

doi:10.5539/jms.v4n4p1 URL: http://dx.doi.org/10.5539/jms.v4n4p1

\begin{abstract}
This paper is set within a framework of re-conceptualising sustainable livelihoods and enterprises by identifying the multidimensionality of rural livelihood diversification within small farm households in Southern Ghana. Contributing to and providing links between the different rural livelihood strategies and household well-being, this paper investigates the nature and extent to which livelihood diversification impacts of households strategies towards wealth accumulation, survival and resilience to impoverishment. The study undertakes a critical evaluation of the impact and relationship between poverty reduction projects implemented through District Assemblies and those initiated by community organisations and households. Empirical research involving questionnaire surveys, interviews and focus group meetings was used in studying rural farm households in Akuapem North and Dangme West Districts in Southern Ghana. The paper points to the existence of significant divergence in outcomes of livelihood diversification. Also, the overall impact of diversification and formal intervention strategies towards alleviating poverty within small farm household's economy is limited and not sustainable with survival being the more probable outcome of diversification.
\end{abstract}

Keywords: Ghana, livelihoods diversification, accumulation, survival, resilience, household enterprises

\section{Introduction}

Livelihood diversification activities have become an important income generating strategy for rural small farm households throughout the developing world. Although these are found to account for only part of the total income of rural small farm households, the diversified non-farm sector has gained in importance for rural household economies (Asssan \& Beyene, 2013; Rigg, 2006; Bryceson, 2004).

A livelihood is described in this study as comprising of systematic activities or enterprises undertaken by individuals/households using their capabilities and available opportunities to derive material/ financial reward and/ or improved status, or to produce food for sale rather than for household consumption (Hussein \& Nelson, 1998; Scoones, 1999; Assan, 2008). It has been argued that rural households adopt livelihood diversification strategies in an attempt to generate livelihoods and enterprises that can cope with and recover from stress and shocks, and in this way maintain and enhance their capabilities and assets both for the present and the future (Escobal, 2001; Barrett et al., 2001; Ellis et al., 2003). In addition, Hussein and Nelson (1998), Barrett et al. (2001) and Woldenhanna and Oskam (2001) are of the view that in the face of credit constraints and the withdrawal of government subsidies on agricultural inputs, income from livelihood diversification activities/enterprises provides cash to invest in productivity-enhancing inputs (Bahiigwa et al., 2005). Income from non-farm enterprises will also be invested in on-farm activities through intensification and extensification (Tiffen, 2003; Holden et al., 2004). In this argument, diversification is perceived as a means of enhancing the performance of the food system, leading to an increase in rural incomes and lower urban food prices (Ellis, 2002). Livelihood diversification will thus increase access and availability of food products and augment food storage and consumption (Block \& Webb, 2001). Proponents of diversification further argue that it will help the rural economy to grow fast and equitably (Holden et al., 2004). 
Moreover, livelihood diversification within the context of a sustainable livelihood framework is perceived to be an effective policy strategy for the reversal of the persistent state of rural household deprivation (Devereux et al., 2003). They argue that deprivation within rural farm households is an endemic and growing problem throughout sub-Saharan Africa. The cause of this growth is complex and quite difficult to understand. However, some authors refer to the inadequacy of rural household resources and the structural inability to sustain reasonable growth and development as the major causes (Scoones, 2000). Diversification in this context is argued to open avenues for growth by providing extra incomes and resources that would otherwise be absent from the rural household (Ellis et al., 2003).

The paper examines the impact of rural livelihood diversification to non-farm enterprises within small farm households to ascertain whether such enterprises which were establishes through formal and informal intervention programs towards poverty alleviation result in wealth accumulation and improvement of well-being. The paper is organised as follows. Section 1 provides a brief introduction to the issues raised in the paper. Section 2 provides a review on the nature and the extent of the impacts of diversification on rural households whilst section 3 discusses the study context and fieldwork strategy of the paper. Section 4 presents empirical results from both qualitative and quantitative data generated by the study. Conclusion remarks and policy implications recommendations are found in section 5 .

\section{Rural Livelihood Diversification: Accumulation, Survival and Despair?}

Hussein and Nelson (1998, p. 3) define livelihood diversification as 'attempts by individuals and households to find new ways to raise incomes and reduce risk (economic, environmental and social), which sharply differs by the degree of freedom of choice (to diversify or not) and the reversibility of the outcome'. They argue that it includes activities both on and off the farm that are undertaken to generate income additional to that of the household's main agricultural activities. They added that this supplementation is achieved through production of other agricultural and non-agricultural goods and services, the sale of waged labour, self-employment in small firms, and other strategies employed to spread risk. Lemi (2005) further argued that the level of intensity and participation of rural households in diversifications was not uniform. Demographic factors, such as the age and gender of the household head, dependency ratio and number of female household members are determinants of participation. He pointed out that intensity is also affected by the size of land holdings, value of livestock owned and level of income from crop production.

The on-going debate on rural livelihoods is not clear on whether diversification into small enterprises results in sustainable wealth accumulation or a desperate strategy for survival within resource poor societies (Assan \& Beyene, 2013). Ellis (1998) perceived diversification to be an accumulation strategy which could lead to improvement in incomes and assets. According to Whitehead and Kabeer (2001) and Dercon and Krishnan (1996), accumulation through diversification may not be equally available to all rural households. They consider diversification to provide one source of surplus for investing into productivity improvement in agricultural methods and other forms of accumulation.

Within the diversification literature, there has been much debate concerning the ability of a diversified activity to provide accumulation and/or survival options to rural households (Whitehead \& Kabeer 2001). The outcome has been inconclusive. However, some authors arrive at conclusions that can only be accepted cautiously; since their studies are based either on limited data/experience, or are restricted in scope to specific geographical locations (for example: Reardon, 1997; Hussein \& Nelson, 1998; Whitehead \& Kabeer, 2001). These authors are confident that $30 \%$ to $50 \%$ of African rural households derive income from non-farm enterprises, but they are not able to state whether these incomes are earned for survival or accumulation. Reardon (1997) blames the lack of conclusiveness on the scarcity of empirical research findings in relation to the rural non-farm sector, especially in Africa. Diversification, according to him, offers a pathway out of poverty but he does not say whether it is indicative of survival or accumulation strategies.

Whitehead and Kabeer (2001) hypothesized that commercialisation of agricultural activities could lead to accumulation. They cite the use of irrigated agriculture in the cultivation of rice and vegetables as a form of on-farm diversification that could yield high levels of return and accumulation. Carswell (1997) also takes this position in her study of agricultural intensification activities in East Africa. This then poses the critical question as to what factors enable a household to accumulate or diversify their enterprises to the extent that it will ensure accumulation or a sustainable level of socio-economic improvement.

de Janvry and Sadoulet (2001) have reported forms of accumulation in the rural non-farm service sector activities such as tourism and waged labour activities. They conceded that the rural non-farm service sector has a better potential in enhancing accumulation from diversification. This could be attributable to the fact that this 
area does not require much capital investment and mainly requires an individual's skills. In the absence of the need for a major financial investment, proprietors of non-farm enterprises tend to consider the greater part of their returns as profits (Assan, 2013).

By contrast, Davies (1996) and Neihof (2004) emphasize the survival motivation in the nature of diversification. They argued that diversification has become a form of temporary adaptation to risk and hence is a strategy that is necessarily employed to ensure survival rather that accumulation. Beck (1989: 23) describes survival strategies as the activities of the poor people in times of stress which they see as crucial for the continued running of their households. It is considered as a stopgap or filler, in the sense that it merely allows households to bridge economic gaps on a temporary basis, only to encounter them again in the near future (Neihof, 2004). Another view with similar emphasis is that diversification represents a survival strategy, a response to crises that is associated with very low returns and deprivation (Reardon \& Vosti, 1995; Reardon \& Taylor, 1996; Whitehead $\&$ Kabeer, 2001). The proponents of this view argue that it forms part of survival strategies in areas of high agro-climatic and economic risk.

Again, Davies (1996) argues that diversification into local enterprises mainly enhances the ability to survive, and serves as a source of insurance against indebtedness and borrowing. In her study of seasonality and coping strategies as practised by five village councils in central Mali, Cekan (1992) suggested that rural households are able to derive mainly survival benefits from diversification. It could however be noted that rather than employing such survival strategies in times of crises, several small farm households employ such strategies for the greater part of the year. Hence, such survival strategies rather describe permanent adaptive strategies.

It is evident that predicting the outcome of a diversified activity can be difficult (Rigg, 2006). There is therefore the need for further understanding of the varying context, scale and size of the outcomes of livelihood diversification. It is also useful to know which rural enterprises are either able to achieve sustainable wealth accumulation and improve the well-being of those engaged in such enterprises and ultimately accelerate poverty reduction.

\section{Study Context and Fieldwork Strategy}

According to Haroun and Oduro (2002), several small farmers in Southern Ghana have taken up non-farm diversification as a means of raising alternative incomes or generate complementary incomes to finance their agricultural enterprises. Non-farm diversification and migration are reported by the same source to have replaced farming as main source of income in some rural households. The overall impact of diversification activities and enterprises on the economy and welfare of small farm households in Ghana and the theoretical implications for the wider study on diversification is not well reported, although the Ghanaian economic recovery model has been employed by several other African countries and it is perceived to successfully address issues relating to the rural and household economy effectively.

This study collected empirical data on household income strategies and sources, assets, access, and expenditure patterns to address the key question raised by the paper: does livelihood diversification result in accumulation of wealth or it only enhances survival and peripheral living conditions?

\subsection{Sampled Study Districts}

Small farm households in Akuapem North and the Dangme West Districts in the South-eastern part of Ghana were selected as the sites for the household data collection. These two districts have large rural populations engaged in food production and also have similar socio-economic and cultural structures. Although geographically located next to each other, the sampled districts are located in two different agro-ecological zones. The households in both these districts are traditionally known to be farmers (Hill, 1965, Benneh, 1971), but are reported by the respective district profiles as diversifying into non-farm enterprises.

The major economic activities undertaken by farm households in both study districts include food crop and vegetable production, pottery, production of beads, bee keeping, cosmetics and quarrying (Assan, 2008; District Profile 2000-2004). This form of diversification has led to the introduction/ adoption of waged labour by some farmers; shortage and high cost of staple food crops have increased the prevailing seasonal and permanent migration as reported by the district profile. By contrast, Akuapem North District has not received any formal government intervention but is experiencing diversification and the expansion of non-farm enterprises although this district is considerably more endowed (District Profile, 2001).

\subsection{Fieldwork Strategy}

A participatory multi-stage research strategy, triangulating quantitative and qualitative methods has been adopted (Kitchen \& Tate, 2000). The study used a combination of quantitative (household survey), qualitative (individual 
and group interviews) and participatory (wealth ranking, group discussions and key informant analysis) methods within a small-scale sample survey following a reorganised research strategy in livelihood studies that purposively sampled communities and households involved in diversified enterprises as recommended by de Haan and Zoomers (2005) and Ellis (2000).

\subsubsection{Selection of Communities}

The eight communities were randomly selected from each of the two districts using the respective district economic baseline studies and district profiles (ODI, 2001). In doing this, all the farming communities that are involved in non-farm activities as listed by the district profiles were initially selected purposively.

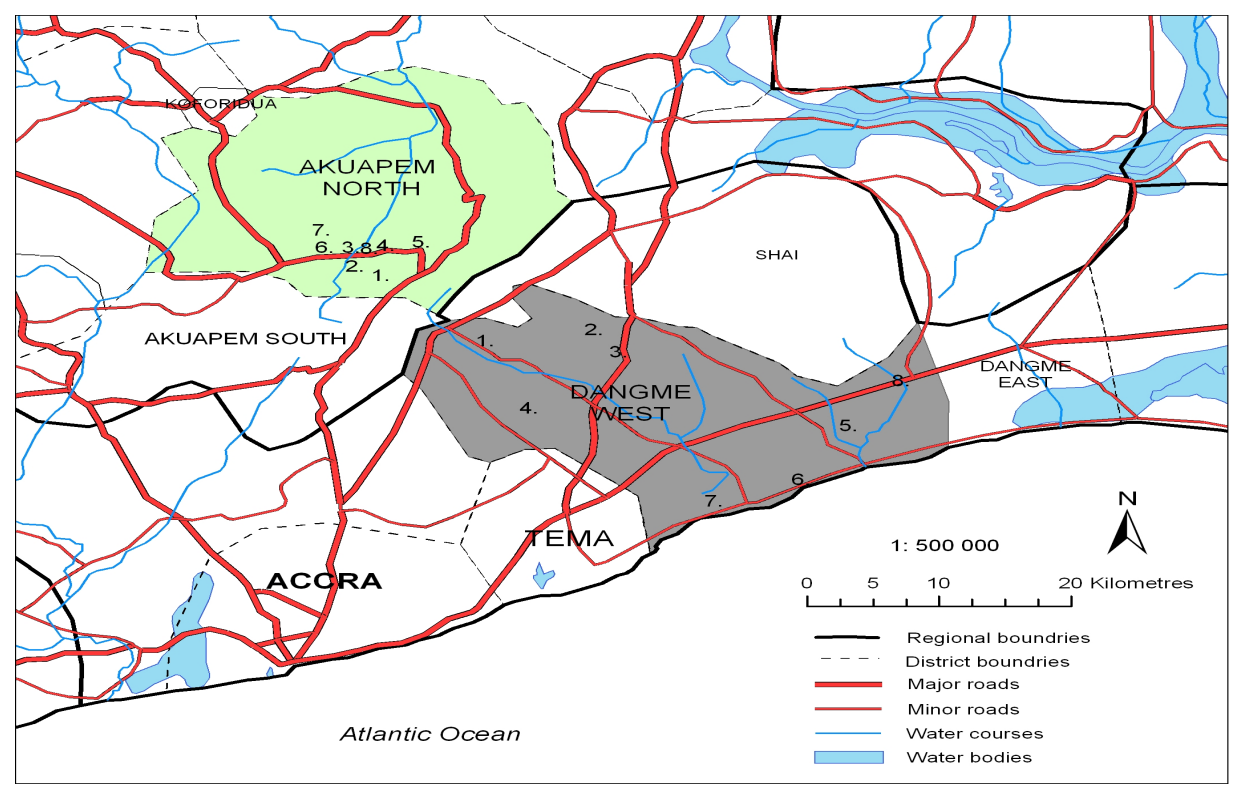

Figure 1. Map of study districts and sampled communities

Source: Author (2014).

The next stage of the sampling process involved the selection of the study households which was the unit of analysis of the study. Household selection by this study required households to have been involved in diversification for at least five years and consider the diversified enterprises as part of their income tree and household budget, and therefore invest their time and resources in it. According to Barlett (1986, p. 3), the farm household is the core component of human cultural and economic organisation and provides a framework for many socio-economic activities. Toulmin and Guèye (2005, p. 160) define a household as a unit of production which farms a common field and eats from a common granary. A household is also described as a group of people who share the same domestic economy or eat from the same bowl (Barlett 1989, p. 6).

Diversified households in each community were purposively sampled and listed using a baseline data provided by the District Assembly representative of the respective communities, the District Profiles and Community Baseline Reports. These lists were verified by rapid appraisals conducted by the research team. A systematic random sampling method was used to select fifty households from each district. Within the household, household heads, their spouses and economically active members were selected as the key respondents of the study, as they are often the decision-makers and contributors to the household budget (Toulmin \& Guèye, 2005). 
Table 1. Household characteristics of study population

\begin{tabular}{lllllll}
\hline $\begin{array}{l}\text { Measures of } \\
\text { Central Tendency }\end{array}$ & $\begin{array}{l}\text { Total household } \\
\text { size }\end{array}$ & $\begin{array}{l}\text { Number of } \\
\text { Males in } \\
\text { Households }\end{array}$ & $\begin{array}{l}\text { Number of } \\
\text { Females in } \\
\text { Households }\end{array}$ & $\begin{array}{l}\text { Number of } \\
\text { Male Adults }\end{array}$ & $\begin{array}{l}\text { Number of } \\
\text { Female Adults }\end{array}$ & $\begin{array}{l}\text { Number of } \\
\text { Economically } \\
\text { Active Members }\end{array}$ \\
\hline Sum & 751 & 360 & 391 & 256 & 299 & 305 \\
Mean & 7.51 & 3.64 & 3.95 & 2.59 & 3.02 & 3.05 \\
Median & 6 & 3 & 3 & 2 & 3 & 2 \\
Mode & 6 & 3 & 1 & 1 & 1 & 1 \\
Minimum & 4 & 2 & 12 & 11 & 11 & 10 \\
Maximum & 15 & 11 & & & & \\
\hline
\end{tabular}

Number of households is 100 .

Table 2. Household characteristics of study population by District Akuapem North

\begin{tabular}{|c|c|c|c|c|c|c|}
\hline $\begin{array}{l}\text { Measures of } \\
\text { Central Tendency }\end{array}$ & $\begin{array}{l}\text { Total household } \\
\text { size }\end{array}$ & $\begin{array}{l}\text { Number of Males } \\
\text { In Households }\end{array}$ & $\begin{array}{l}\text { Number of } \\
\text { Females In } \\
\text { Households }\end{array}$ & $\begin{array}{l}\text { Household } \\
\text { Members } \\
\text { (excluding } \\
\text { heads) }\end{array}$ & $\begin{array}{l}\text { Male Members } \\
\text { (excluding heads) }\end{array}$ & $\begin{array}{l}\text { Female } \\
\text { Members } \\
\text { (excluding } \\
\text { heads) }\end{array}$ \\
\hline Sum & 367 & 172 & 195 & 267 & 119 & 148 \\
\hline Mean & 7.30 & 3.44 & 3.9 & 5.30 & 2.43 & 3.02 \\
\hline Std. Error of Mean & 0.40 & 0.24 & 0.28 & 0.40 & 0.25 & 0.27 \\
\hline Median & 6 & 3 & 4 & 4 & 2 & 3 \\
\hline Mode & 6 & 3 & 2 & 4 & 2 & 1 \\
\hline Minimum & 4 & 1 & 1 & 2 & 1 & 1 \\
\hline Maximum & 15 & 11 & 9 & 14 & 11 & 8 \\
\hline \multicolumn{7}{|l|}{ Dangme West } \\
\hline Sum & 384 & 188 & 196 & 288 & 137 & 151 \\
\hline Mean & 7.66 & 3.76 & 3.9 & 5.68 & 2.74 & 3.02 \\
\hline Std. Error of Mean & 0.41 & 0.23 & 0.31 & .417 & 0.232 & 0.31 \\
\hline Median & 6 & 3 & 3 & 4.50 & 2 & 2 \\
\hline Mode & 6 & 3 & 3 & 4 & 2 & 2 \\
\hline Minimum & 4 & 2 & 1 & 2 & 1 & 1 \\
\hline Maximum & 15 & 9 & 12 & 13 & 8 & 11 \\
\hline
\end{tabular}

Community durbars (community gatherings of the chief, elders and members of the community) were organised to explain the objectives of the study to the communities and to select key informants. This was followed by a household questionnaire survey. Household heads and their spouses were the key respondents to the questionnaire survey. Economically active members of the households were also interviewed to complete sections on the questionnaire that dealt with their economic activities and their contribution towards household budget. The questionnaire survey was complemented by informal household interviews of all the sampled households and a focus groups discussion meeting in each of the sampled communities. Participants of the focus group meetings were selected randomly with a maximum of eight individuals in a group. The interviews and focus group discussions greatly complemented the questionnaire survey in that they provided meaning and clarity to some of the trends, patterns, phrases, terms and concerns that recurred in the questionnare survey. It also helped to build case studies.

\section{Empirical Findings}

Empirical findings in the form of cross-tabulations from the questionnaire survey and quotations from interviews and focus group discussions on household income strategies and sources, assets management, consumption and expenditure patterns were used to answer five key questions ascertaining the benefits of diversification to the household and under which the empirical results are presented.

\subsection{Livelihood Enterprises of Household Members within Diversification}

Studies of rural non-farm enterprises suggest the gender and socio-economic characteristics of the household head and members and the nature of their economic activities may influence the benefits from livelihood diversification (Ellis, 2003a; Chimhowu \& Hulme, 2006). 
Table 3. Main income activities/enterprises and gender of household head

\begin{tabular}{|c|c|c|c|c|c|c|c|}
\hline \multirow{2}{*}{$\begin{array}{l}\text { Main Income activities } \\
\text { Household Level }\end{array}$} & \multicolumn{4}{|c|}{$\begin{array}{l}\text { Akuapem North } \\
\text { Gender of household head }\end{array}$} & \multicolumn{3}{|c|}{$\begin{array}{l}\text { Dangme West } \\
\text { Gender of household head }\end{array}$} \\
\hline & Male & Female & Total & Male & Female & Total & Total freq. \\
\hline Farming & 9 & 3 & 12 & 8 & 0 & 8 & 20 \\
\hline Bee Keeping \& Fuel wood & 3 & 0 & 3 & 5 & - & 5 & 8 \\
\hline Gari processing \& Trading & 0 & 22 & 22 & - & - & - & 22 \\
\hline Chop bar \& trading & 0 & 1 & 1 & 1 & 1 & 2 & 3 \\
\hline Dressmaking \& trading & 0 & 2 & 2 & 0 & 1 & 1 & 3 \\
\hline Factory worker \&wage labourer & 3 & 0 & 3 & 11 & 0 & 11 & 14 \\
\hline Wood cutter/fuel wood/ cassava harvester & 7 & 0 & 7 & - & - & - & 7 \\
\hline Pottery, Quarrying \& $\quad$ Trading & - & - & - & 1 & 13 & 14 & 14 \\
\hline Sand \& Clay trading \& Wage labour & - & - & - & 5 & 0 & 5 & 5 \\
\hline Soil harvesting \& Wage labour & - & - & - & 9 & 0 & 9 & 9 \\
\hline Total & 22 & 28 & 50 & 35 & 15 & 50 & 100 \\
\hline Chi Squared Test $(P)$ & \multicolumn{7}{|c|}{$P=0.000$} \\
\hline
\end{tabular}

There is a significant relationship between gender of the household head and the main economic activity of the household. Table 3 shows that twenty households indicated farming as their main income activity, and the rest of the sampled households (80) depend on non-farm enterprises for their main income. This pattern has important implications in the sense that all the sampled households had originally been mainly staple crop producers (MOFA 2001). A shift from farming by any single household could influence both local and national food security.

Another interesting pattern observed from Table 3 is that, with the exception of farming, all the households with non-farm enterprises as their main economic activities operated two or more enterprises. The reason for this strategy is to ensure income security. Unlike farming where it is difficult to maintain income security, the sampled households are able to achieve this security by engaging in multiple non-farm activities. This security mechanism works on the basis that when the sale or production levels in one enterprise falls (or fails), the proprietors are able to switch to the other enterprise. The interviews revealed that operating a dual enterprise helps to increase returns and ensure continuity of production and cash income.

It is also observed from Table 3 that some of the enterprises are associated with a particular district. This is because these activities are traditional trades of the natives of these districts and also the raw materials required for such enterprises are located as natural resources in the respective districts. For example, Dangme West has large reserves of clay whilst Akuapem North produces a large quantity of cassava for gari production. The study was also informed that cost of transporting raw materials can be expensive particularly because of the bulky nature of raw materials often attract high fares and does not make some non-farm enterprises worthwhile. A respondent in Dangme West made this comment:

I have particular interest in gari processing but the cassava produced in this district is not as good as that produced for the production of gari in Akuapem. Secondly, it is very expensive to buy cassava from Akuapem because cassava is perishable and the cost of transport is too dear.

The study revealed that most non-farm enterprises are headed by both genders. Arguments for such patterns as expressed by the sample are that some activities were traditionally associated with particular genders in the past, but such traditional views are changing with the advent of diversification. However, specific combinations of activities (e.g. gari processing and trading; pottery and quarrying, factory work and waged labour; sand and stone trading and wage labour; fuel wood and cassava harvesting; soil harvesting and waged labour, bee keeping and fuel wood business) are observed to be associated with either male or females. Such patterns point to the diversification in gender roles and social values (Garcia, 1995). 
Table 4. Economic activity of employed members within the sampled households

\begin{tabular}{|c|c|c|c|c|c|c|}
\hline \multirow[t]{2}{*}{ Economic activity of adult non-household heads } & \multicolumn{2}{|c|}{ Akuapem North } & \multicolumn{2}{|c|}{ Dangme West } & \multicolumn{2}{|l|}{ Total } \\
\hline & Freq. & $\%$ & Freq. & $\%$ & Total N & Total \% \\
\hline $\begin{array}{l}\text { Number of households members operating NF } \\
\text { enterprises as main income activity }\end{array}$ & 127 & 89.9 & 89 & 90.8 & 216 & 84.7 \\
\hline $\begin{array}{l}\text { Number of household members involved in farm } \\
\text { enterprises }\end{array}$ & & 19.1 & 9 & 9.2 & 39 & 15.3 \\
\hline $\begin{array}{l}\text { Number of employed household members within } \\
\text { the sample }\end{array}$ & 157 & 100 & 98 & 100 & 255 & 100 \\
\hline
\end{tabular}

Out of the 255 employed members (non-household heads) within the sampled households, 216 (84.7 percent) are engaged in non-farm enterprise as their main income activities compared to 39 employed members (15.3 percent) involved in farming activities (Table 4). It is also noted that 127 (49.8 percent) of the total number of individual adult members operating non-farm enterprises as their main income activity within the sample are located in Akuapem North compared with 89 (34.9 percent) in Dangme West. The above pattern indicates that like the household heads, the majority of the employed members within the sampled households are also engaged in non-farm enterprises.

The household interviews in Akuapem North suggests that the majority of the economic activity members prefer participating in non-farm enterprises compared to farming because of the possibility of earning quick cash and creating access to interacting with the world outside the village with possibility of stepping outside the cycle of poverty traditionally associated with food crop cultivation and its related discriminatory and repressive land tenure systems.

\subsection{Diversification: Insurance against Asset Smoothing and Asset Disposal?}

Asset smoothing could be described as the act of temporarily disposing off personal or household assets in exchange for cash in times of crises with the intention of reclaiming the asset when the amount borrowed is repaid (Dercon 2000).

Table 5. Objective of engaging in non-farm activities

\begin{tabular}{llll}
\hline Objectives & Akuapem North & Dangme West & Total Frequency \\
\hline Raise cash and accumulate assets & 39 & 46 & 85 \\
$\begin{array}{l}\text { For income security and accumulation \& security } \\
\text { of well being }\end{array}$ & 11 & 4 & 15 \\
Total & 50 & 50 & 100 \\
\hline
\end{tabular}

The need for cash income and also to accumulate income and assets as a form of insurance against financial hardships was mentioned in the household interviews as being vital for both groups (Table 5). The respondents in Akuapem North indicated that diversification not only ensures their survival but is also a security measure against financial pitfalls associated with farming and rural life where incomes are irregular. One male household head in Akuapem North explained that he considered his household's cost of living and budget and decided to diversify with the hope of bringing more money into the household budget. Overall, the sample recognised that other households had taken a similar stock of their economies, hence their reason to diversify.

Only one household confirmed its ability to accumulate from diversification. This household grow rice and vegetables and is also involved in trading of fish and textiles. The couple argued that the trading activities ensure a more regular inflow of extra income, most of which is spent on household consumption and the rest is saved at the bank and for the expansion of trading capital. 
Table 6. Have you disposed of any assets as a smoothing measure in the last year?

\begin{tabular}{llll}
\hline Asset disposal & Akuapem North & Dangme West & Total \\
\hline Yes & 28 & 38 & 66 \\
No & 22 & 12 & 34 \\
Total & 50 & 50 & 100 \\
$P=0.014$ & & & \\
\hline
\end{tabular}

A large proportion of the sampled households (66) have disposed off their valuable assets in exchange for cash on a regular or occasional basis within the last year (Table 6). The reason for asset smoothing varies and is mainly underlined by material lack, food shortage and financial difficulties. Off the households involved in this form of coping strategy or practice, the majority (38) are from Dangme West. It is lamentable that the disposal of assets through smoothing is still employed within the study districts in spite of diversification. Household members explained that asset smoothing is not just a short-term mechanism but also a strategy to forestall the persistent economic difficulties and hardships such as food and income shortages. The study observed a significant difference $(p=0.014)$ between the two districts with regards to smoothing of assets (Table 6). This variation was explained by the fundamental difference in the social capital networks, which are more supportive in Akuapem North. Residents in Dangme West tend to sell valuable personal effects and household belongings to other members of the family or the larger community for cash. Such transactions are often permanent and irreversible.

\subsection{Diversification and Resource Control and Management}

Ellis has considered diversification to augment household's resource management and capacity to control resources (Ellis, 2003a). However, the majority (83) of the sampled households in Southern Ghana indicated that the extent to which their diversified enterprises have helped to control their resources is very low. They concede that diversification has not had much impact on the low resource control processes of their household, especially when there is little left to be used to expand their assets and reduce levels of indebtedness.

In the light of the above findings, the study looked at the issue of household savings and how these have been influenced by diversification. The outcome of this analysis is disturbing as the majority of the households (77) indicated that the effect of diversification on their savings is very low. The household interviews revealed that most of the money obtained is reinvested in non-farm enterprises and debt servicing rather than improving consumption and well-being.

The study used questionnaire surveys and household interviews to elicit information on household income sources and expenditure which were statistically analysed to identify household income patterns and expenditure priorities. The total expenditure on borrowing and repayments of credit ( $\$ 46.02$ million) by the sampled households is more than the amount they expended on savings and investments ( $\varnothing 30.60$ million) (Tables 7 and 8 ). Although this is consistent with the findings of the GLSS (2000), it suggests that diversification has not been able to reverse the pattern of indebtedness.

Table 7. Total expenditure on household savings and investments

\begin{tabular}{llll}
\hline Measures of Central Tendency & $\begin{array}{l}\text { Akuapem North } \\
\text { (million } \phi)\end{array}$ & $\begin{array}{l}\text { Dangme West District } \\
\text { (million } \phi)\end{array}$ & $\begin{array}{l}\text { Total sample } \\
\text { (million } \phi)\end{array}$ \\
\hline Sum & 18.70 & 11.90 & 30.60 \\
Mean & 0.3740 & 0.2380 & 0.3060 \\
Std. Deviation & 0.17 & 0.15 & 0.17164 \\
Maximum & 0.80 & 1.00 & 1.00 \\
Minimum & 0.10 & 0.10 & 0.10 \\
Per capita & 0.050953 & 0.030989 & 0.040745 \\
\hline Total $(\mathrm{N})$ & 50 & 50 & 100 \\
\hline
\end{tabular}


Table 8. Monetary value of debt (all cash and items obtained on credit)

\begin{tabular}{llll}
\hline Measures of Central Tendency & $\begin{array}{l}\text { Akuapem North } \\
(\text { million } \phi)\end{array}$ & $\begin{array}{l}\text { Dangme West District } \\
\text { (million } \not \text { ) }\end{array}$ & $\begin{array}{l}\text { Total sample } \\
\text { (million } \phi)\end{array}$ \\
\hline Sum & 21.72 & 24.30 & 46.02 \\
Mean & 0.4344 & 0.4860 & 0.4602 \\
Std. Deviation & 0.18 & 0.24 & 0.21 \\
Maximum & 1.00 & 1.50 & 1.50 \\
Minimum & 0.20 & 0.20 & 0.20 \\
Range & 0.80 & 1.30 & 1.30 \\
\hline Total $(\mathrm{N})$ & 50 & 50 & 100 \\
\hline
\end{tabular}

The study proceeded to analyse and compute the expenses made by the sampled households as well as the amounts spent on debt repayment using date generated from the household questionnaire and interviews. An important finding made by the study in this regard is the high incidence of indebtedness in the two study districts and the significant difference between the average amounts of money borrowed per household in Akuapem North ( $\varnothing 0.4344$ million) compared to that of Dangme West ( $\notin 0.4860$ million). The total amount of money borrowed by the sample in Dangme West ( $\$ 24.30$ million) which is significantly higher than the amount borrowed by the sample in Akuapem North ( $\$ 21.72$ million). This demonstrates the prevailing vulnerability, and that the poverty reduction program and for that matter diversification has not been able to erase the substantial deprivation prevalent amongst households in Dangme West.

Again, it is also noted (Table 7) that the average amount spent on savings and investments for both groups are lower than household debts, although savings per household in Akuapem North is significantly higher ( $\$ 509$, 530) than that of Dangme West $(\$ 309,890)$. This indicates not only that the diversified households in Akuapem North are more likely to sustain their economy and enterprises in the face of credit constraint compared to those in Dangme West, but it also shows the perpetuation of indebtedness and the fragile economies of the sample in Dangme West. This proposition is confirmed by the larger savings-debts deficit per annum of Dangme West ( $\phi$ 12.4 million), which is more than three times that of Akuapem North ( $\$ 3.02$ million) (Table 8). This is calculated by subtracting total amount of debt from total amount of savings and investments (Tables 7 and 8 ). It could also be deduced from the negative savings to debt ratio of the sample that such patterns denote abject deprivation and lessen ability to manage risks and elements which diversification is perceived to eliminate or reduce (Sen 1985). Generally, the low level of savings and investments associated with both study groups gives cause for concern, as life devoid of extreme poverty and its reduction seems more and more remote.

In this line, the study revealed that acquisition and maintenance of assets through diversification is very low as indicated by majority (93) of the sampled households. This is because the need to meet other household needs, largely for consumption purposes, makes it difficult to acquire electronic and other physical assets. The majority of households covered by the present study highlighted the lack of livelihood and income security as a factor that caused them to diversify, and argued that they still do not enjoy income security in spite of their diversification.

\subsection{Household Food Security and Ability to Afford of Social Services}

This section evaluates the impact of diversification on household food security in an attempt to ascertain the perception of the households regarding diversification and its influence on household capacity and ability to secure food and feed its members consistently.

When asked to evaluate the impact of diversification on household food security, most of the sampled households (71) said the impact is moderate. They argued that although a large proportion of their income from diversification is used to meet household food needs, the effect has not yielded the transformation that is expected to alleviate their recurrent seasonal hunger. The respondents explained that several households cannot afford to eat what they desire or buy food that will be sufficient to feed all of its members. Diversification has had very little positive impact on the household's menu. Participants in the focus group meetings in both study districts explained that the extent to which income from diversification has assisted in the introduction of new food items on the household's menu is small or very small.

With the introduction of user charges for medical care and education, it has become critical for rural households to be able to raise required amount of money to access these facilities. The study therefore sought to see if diversified households are able to afford education fees or access medical care under the Ghana Health and Education Services by virtue of additional income. 
Table 9. Ability to afford present medical bills before and after diversification

\begin{tabular}{|c|c|c|c|c|}
\hline \multirow[t]{2}{*}{ Ability to afford medical bills } & \multicolumn{2}{|c|}{ Akuapem North } & \multicolumn{2}{|c|}{ Dangme West } \\
\hline & Before & After & Before & After \\
\hline No & 5 & 6 & 15 & 17 \\
\hline Unable to pay most times & 30 & 32 & 25 & 27 \\
\hline Yes & 15 & 12 & 10 & 6 \\
\hline Total & 50 & 50 & 50 & 50 \\
\hline
\end{tabular}

Table 10. Ability to afford school fees before and after diversification

\begin{tabular}{lllll}
\hline Ability to pay fees & Akuapem North & Dangme West & \\
\hline & Before & After & Before & After \\
No & 18 & 21 & 30 & 35 \\
Unable to pay most times & 10 & 21 & 10 & 11 \\
Yes & 22 & 8 & 10 & 4 \\
Total & 50 & 50 & 50 & 50 \\
\hline
\end{tabular}

Ability to afford medical services: An issue of serious importance identified by the study is the rising number of households that are unable able to pay for their medical care in spite of diversification. The household interviews showed that most households still struggle to pay for the medical care of their members. This is quite disappointing because one would expect that earning additional income from diversification would make it possible for most of the households, if not all, to overcome such an important barrier. It suggests that although there is the need to make medical facilities available and accessible by virtue of their location, the ability to afford and to use them is more important. A household head explained by saying: my household has to use traditional herbal clinics, for no other reason than that they are far less expensive than the orthodox medical treatment. The basic implication of this pattern is that the increased cost of medical care is excluding some rural households from accessing medical care. This type of social exclusion directly deprives the household of its dignity which pushes them further into deprivation.

Ability to afford school fees: The payment of school fees in secondary and tertiary institutions is a great drain on the resources of parents, especially those from small farm household. Over half of the respondents are not able to pay their children's school fees (Table 10). The obvious implication is that many rural children will be excluded from school for most of the academic year. Staff of Ministry of Education in both districts confirmed the reported poor fees payment patterns. This is consistent with the findings of Ghana Core Welfare Questionnaire Survey (2001) on school attendance and rising dropout rates in communities in Southern Ghana. Considering that their diversified activities could increase their incomes but not sufficient to afford children's school fees makes their inability to meet this objective lamentable. This shows that diversifying into alternative forms of employment activities still provide the needed cash income; this is short-lived and makes little or no impact on household well being in the long term.

\section{Policy Conclusion}

One particular policy program with extended theoretical underpinnings was the Structural Adjustment Program of which Ghana has been hailed as an icon of success by the World Bank (Horton et al., 1994). However, evidence from several studies, including Bryceson $(2000,2002,2004)$ and this paper, seems to point to the fact that rural communities have still not recovered from the negative shocks of adjustment and economic liberalisation policies implemented in the 1980s and 90s. Bryceson (2002) concluded that Structural Adjustment Programs and market liberalisation policies in Africa and Ghana in particular have removed safety nets and eroded local economies and social communities as argued by Although the sustainable framework suggests the achievement of accumulation from diversification within the rural economy is feasible, this study has shown that such a benefit is not likely for most rural households with the obvious alternative of survival being the more probable outcome of diversification.

Livelihood Diversification is associated with outcomes which vary with geographical locations. It is noted that the outcomes of diversification are not uniform with respect to derived benefits and effects of the benefits on the household as projected by Assan and Beyene (2013), Assan et al. (2009) and Scoones (1998). Rather than improving well-being and reducing poverty unilaterally, this paper argues that the outcomes from diversification vary from one geographical area to the other and from one district to another as argued by Reardon and Taylor (1996). 
In spite of the attempts towards labour specialisation by individuals and households as recommended by Bryceson (2002), and the proliferation in wage labour associated with diversification which is encouraged by the advocates of free market and liberalisation, returns are still not commensurate to investment as would have been expected in an efficient free market and contrary to predictions by the proponents of Structural Adjustment (see World Bank 2000).

Again, diversification does not necessarily offer pathways out of deprivation as suggested by Reardon (1997). Empirical evidence presented by this paper is consistent with that presented by Orr and Mwale (2001) in the case of small farm households in Malawi and Carswell (2000) but contradicts the views of Whitehead and Kabeer (2001). The pattern of disposal of valuable tangible assets in exchange of cash as a result of extreme economic hardships is in contrast with the proposed benefits of liberalisation to the rural farm household. This observation is in contrast to theoretical propositions on adjustment and liberalisation policies presented by Ahmed and Lipton (1997). The present study offers empirical evidence that largely identified diversification as a strategy for survival as argued by Assan et al (2009).

Belshaw (2002) is of the view that for accumulation to occur income generation processes should be accompanied by cost minimising policies, market linkages and risk reduction. These policies are not sufficiently pursued within local enterprises in Ghana. Effective poverty alleviation in Southern Ghana must therefore involve geographical targeting and pragmatic policy strategies that encourage private sector participation in local economic development beyond the present scheme that is largely coordinated and managed by the respective District Administrations and Non-governmental Organisations (NGOs).

\section{References}

Ahmed, I. I., \& Lipton, M. (1997). Impact of Structural Adjustment on Sustainable Rural Livelihoods: A Review of the Literature. IDS Working Paper 62. Brighton: Institute of Development Studies.

Akuapem North District. (2001). The Akuapem North District Profile. Akropong: Ghana Ministry for Local Government and Rural Development.

Assan, J. K. (2008). Generational Differences in Internal Migration: Derelict Economies, Exploitative Employment and Livelihood Discontent. International Development Planning Review, 30(4), 377-398. http://dx.doi.org/10.3828/idpr.30.4.4

Assan, J. K., \& Beyene, F. R. (2013). Livelihood Impacts of Environmental Conservation Programmes in the Amhara Region of Ethiopia. Journal of Sustainable Development, 6(10), 87-105. http://dx.doi.org/10.5539/jsd.v6n10p87

Assan, J. K., \& Kumar P. (2009) Policy Arena - Livelihood Options for the Poor in the Changing Environment, Journal of International Development 21(3) 393-402. http://dx.doi.org/10.1002/jid.1565

Assan, J. K., Caminade, C., \& Obeng, F. (2009). Environmental Variability and Vulnerable Livelihoods: Minimising Risks and Optimising Opportunities for Poverty Alleviation. Journal of International Development, 2l(3), 403-418. http://dx.doi.org/10.1002/jid.1563

Bahigwa, G., Mdoe, N., \& Ellis, F. (2005) Livelihoods Research Findings and Agricultural Growth. IDS Bulletin 36(2), 115-120. http://dx.doi.org/10.1111/j.1759-5436.2005.tb00207.x

Barlett, P. F. (1989). Introduction: Dimensions and Dilemmas of House holding. In R. R. Wilk (Ed.), The Household Economy: Reconsidering the Domestic Mode of Production. Colorado and London: Westview Press Inc.

Barrett, C. B., Reardon, T., \& Webb, P. (2001). Non-farm Income Diversification and Household Livelihood Strategies in Rural Africa: Concepts, Dynamics, and Policy Implications. Food Policy, 26(4), 315-331. http://dx.doi.org/10.1016/S0306-9192(01)00014-8

Beck, T. (1989). Survival Strategies and Power amongst the Poorest in a West Bengal Village. IDS Bulletin, 20(2), 23-32. http://dx.doi.org/10.1111/j.1759-5436.1989.mp20002004.x

Belshaw, D. (2002). Strategising Poverty Reduction in Sub-Saharan Africa: The Role of Small-Scale Agriculture. Journal of Agricultural Economics, 53(2), 161-193. http://dx.doi.org/10.1111/j.1477-9552.2002.tb00016.x

Berry, S. (1989). Social Institutions and Access to Resources. Africa, 59(1), 41-55. http://dx.doi.org/10.2307/1160762

Block, S., \& Webb, P. (2001). The Dynamics of Livelihood Diversification in Post-Famine Ethiopia. Food Policy, 26(4), 333-350. http://dx.doi.org/10.1016/S0306-9192(01)00015-X 
Bryceson, D. F. (2000). Rural Africa at the Crossroads: Livelihood Practices and Policies. Natural Resources Perspectives Number 52. London: ODI.

Bryceson, D. F. (2002). The Scramble in Africa: Re-orientating Rural Livelihoods. World Development, 30(5), 725-739. http://dx.doi.org/10.1016/S0305-750X(02)00006-2

Bryceson, D. F. (2004). Agrarian Vista or Vortex: African Rural Livelihood Policies. Review of African Political Economy Volume 102. http://dx.doi.org/10.1080/0305624042000327831

Canagarajah, S., Newman, C., \& Bhattamishra, R. (2001). Non-Farm Income, Gender, and Inequality: Evidence from Rural Ghana and Uganda. Food Policy, 26(4), 405-420. http://dx.doi.org/10.1016/S0306-9192(01)00011-2

Carswell, G. (1997). Agricultural Intensification and Rural Sustainable Livelihoods: A Think Piece. IDS Working Paper Number 64. Brighton: Institute of Development Studies.

Carswell, G., Hussein, K., McDowell, \& Wolmer, W. (1997). Sustainable Livelihoods: A Conceptual Approach. Brighton: Institute of Development Studies. Mimeo.

Cekan, J. (1992). Seasonal Coping Strategies in Cetral Mali: Five Villages During the Soudure. Disaster, 16(1), 66-73. http://dx.doi.org/10.1111/j.1467-7717.1992.tb00377.x

Chambers, R., \& Conway G. (1992). Sustainable Livelihoods: Practical Concepts for the $21^{\text {st }}$ century. IDS Discussion Paper 296. Brighton: Institute of Development Studies.

Chimhowu, A., \& Hulme, D. (2006). Livelihood Dynamics in Planned Spontaneous Resettlement in Zimbabwe: $\begin{array}{llll}\text { Converging and Vulnerable. World } & \text { 728-750. }\end{array}$ http://dx.doi.org/10.1016/j.worlddev.2005.08.011

Chuta, E., \& Leidholm, C. (1990). Rural Small Scale Industry: Empirical Evidence and Policy Issues. In C. Eicher \& J. Staatz (Eds.), Agricultural Development in the Third World. Baltimore: John Hopkins University Press.

Clark, G. (1995). Onions Are My Husbands. Chicago: University of Chicago Press.

Dangme West District of Ghana. (2000-2004). The Dangme West District Profile. Dodowa: Ministry for Local Government and Rural Development.

Dapaah, S. K. (1992). Structural Adjustment programme in Ghana and its Impact on the Fertilizer Privatisation. Lome: Fertilizer Trade and Marketing Information Network.

Davies, S. (1996). Adaptable Livelihood. London: Macmillan Press.

Davies, S. (1996). Adaptable Livelihoods: Coping with Food Insecurity in the Malian Sahel. Science Technology and Development, 14(1), 144-156.

de Haan, L., \& Zoomers, A. (2005). Exploring the Frontier of Livelihoods Research. Development and Change, 36(1), 27-47. http://dx.doi.org/10.1111/j.0012-155X.2005.00401.x

de Janvry, A., \& Sadoulet, E. (2001). Income Strategies among Rural Households in Mexico: The Role of $\begin{array}{llll}\text { Off-farm Activities. } & \text { World } & \text { 29velopment, }\end{array}$ http://dx.doi.org/10.1016/S0305-750X(00)00113-3

Dercon, S. (2000). Income Risk, Coping Strategies and Safety Nets. Oxford: Centre for the Study of African Economies.

Dercon, S., \& Krishnan, P. (1996). Income Portfolios in Rural Ethiopia and Tanzania: choices and constraint. Journal of Development Studies, 32(6), 850-875. http://dx.doi.org/10.1080/00220389608422443

Devereux, S., Teshome, A., \& Sabates-Wheeler, R. (2005). Too Much Inequality? Inequality and Stagnation Ethiopian Agriculture. IDS Bulletin, 36(2), 121-126. http://dx.doi.org/10.1111/j.1759-5436.2005.tb00208.x

Duncan, B. A. (2004). Women in Agriculture in Ghana. Accra: Friedrich Ebert Siftung.

Ellis, F. (1998). Household Strategies and Rural Livelihood Diversification. Journal of Development Studies, 35(1), 1-38. http://dx.doi.org/10.1080/00220389808422553

Ellis, F. (1999). Rural Livelihood Diversity in Developing Countries. Natural Resource Perspective Number 40. London: ODI.

Ellis, F. (2000). Rural Livelihoods and Diversity in Developing Countries. Oxford: Oxford University Press. 
Ellis, F., \& Bahiigwa, G. (2003). Livelihoods and Rural Poverty Reduction in Uganda. World Development, 31(6), 1495-1510. http://dx.doi.org/10.1016/S0305-750X(03)00111-6

Ellis, F., \& Freeman, H. A. (2004). Rural Livelihoods and Poverty Reduction Policies. London: Routledge.

Ellis, F., Kutengule, M., \& Nyasulu, A. (2003). Livelihoods and Rural Poverty Reduction in Malawi. World Development, 31(9), 1495-1510. http://dx.doi.org/10.1016/S0305-750X(03)00111-6

Ellis, K., \& Mdoe, N. (2003) Livelihoods and Rural Poverty Reduction in Tanzania. World Development, 31(8), 1367-1384. http://dx.doi.org/10.1016/S0305-750X(03)00100-1

Escobar, J. (2001). The Determinants of Non-Farm Income Diversification in Rural Peru. World Development, 29(3), 497-508. http://dx.doi.org/10.1016/S0305-750X(00)00104-2

Gerner, H. E. K., Asante, O., Owusu-Bennoah, E., \& Marfo, K. (1995). Ghana fertilizer Privatisation Scheme: Private Sector Role and Public Sector Responsibilities. Alabama: IFAD.

Ghana Statistical Service. (2000). Ghana Living Standards Survey: Report of the Forth Round. Accra: Ghana Statistical Service.

Ghana Statistical Service. (2001). Core Welfare Indicators Questionnaire (CWIQ) Survey 1997. Accra: Statistical Service.

Haroun, A., \& Oduro, M. A. (2002). Access to Markets, Income Diversification and Sustainable Livelihoods. Ghana Centre for Policy Analysis Issues Paper on Agriculture, Accra.

Holden, S., Shiferaw, B., \& Pender, J. (2004) Non-Farm Income, Household Welfare, and Sustainable Land Management in a Less-Favoured Area in the Ethiopian Highlands. Food Policy, 29(4), 369-392. http://dx.doi.org/10.1016/j.foodpol.2004.07.007

Hussein, K., \& Nelson, J. (1998) Sustainable Livelihoods and Livelihood Diversification. IDS Working Paper Number 69. Brighton: Institute of Development Studies.

Kitchin, R., \& Tate, N. J. (2000) Conducting Research into Human Geography. Essex: Pearson Education Ltd.

Leechor, C. (1994). Ghana: Frontrunner in Adjustment. In I. Husain \& R. Faruquee (Eds.), Adjustment in Africa: Lessons from country case studies. Washington DC: The World Bank.

Ministry of Food and Agriculture. (2001). Accelerated Agricultural Growth and Development Strategy in Support of Ghana's Vision 2020. Accra: MOFA.

Niehof, A. (2004). The Significance of Diversification for Rural Livelihood Systems. Food Policy, 29(4), 321-338. http://dx.doi.org/10.1016/j.foodpol.2004.07.009

Reardon, T. (1997). Using Evidence of Household Income Diversification to Inform Study of the Rural Non-farm Labour Market in Africa. World Development, 25(5), 735-747. http://dx.doi.org/10.1016/S0305-750X(96)00137-4

Reardon, T., \& Taylor, J. E. (1996). Agroclimatic Shocks, Income Inequality, and Poverty: Evidence from Burkina Faso. World Development, 24(5), 901-914. http://dx.doi.org/10.1016/0305-750X(96)00009-5

Reardon, T., \& Vosti, S. A. (1995). Links between Rural Poverty and the Environment in Developing Countries: Asset Categories and Investment Poverty. World Development, 23(9), 1495-1506. http://dx.doi.org/10.1016/0305-750X(95)00061-G

Reardon, T., Berdegue, J., \& Escobar, G. (2001). Rural Non-farm Employment and Incomes in Latin America: Overview and Policy Implications. World Development, 29(3), 395-409. http://dx.doi.org/10.1016/S0305-750X(00)00112-1

Reardon, T., Stamoulis, K., Cruz, M. E., Berdegue, J., \& Banks, B. (1998). Rural Non-Farm Incomes in Developing Countries. Rome: FAO.

Rigg, J. (2006). Land, Farming, Livelihoods, and Poverty: Rethinking the Links in the Rural South. World Development, 34(1), 180-202. http://dx.doi.org/10.1016/j.worlddev.2005.07.015

Sarris, A., \& Shams, H. (1991). Ghana under Structural Adjustment: The impact on agriculture and rural poor. New York: International Fund for Agricultural Development and New York University Press.

Scoones, I. (1998). Sustainable Rural Livelihoods: A Framework for Analysis. IDS Working Paper Number 72. Brighton: Institute of Development Studies.

Sen, A. (1985a). Commodities and Capabilities. Amsterdam: Elsevier Science Publishers. 
Taylor, D. R. F., \& Mackenzie, F. (Eds.). (1992). Development from Within: Survival in Rural Africa. London: Routledge.

Tiffen, M. (2003). Transition in Sub-Saharan Africa: Agriculture, Urbanisation and Income Growth. World Development, 31(8), 1343-1366. http://dx.doi.org/10.1016/S0305-750X(03)00088-3

Toulmin, C., \& Gueye B. (2005). Transformation in Regional Agriculture and Family Farming. In R. Cline-Cole \& E. Robson (Eds.), West African Worlds: Paths through Socio-economic Change, Livelihoods and Development (pp. 151-190). London: Pearson.

United Nations Development Programme. (1999b). Sustainable Livelihoods Concept Paper [On-line]. Retrieved from http://www.undp.org/sl/docs

Whitehead, A., \& Kabeer, N. (2001). Living With Uncertainty: Gender, Livelihoods and Pro-Poor Growth in Rural Sub-Saharan Africa. IDS Working Paper Number 134. Brighton: Institute of Development Studies.

Woldenhanna, T., \& Oskam, A. (2001). Income Diversification and Entry Barriers: Evidence from the Tigray Region of Northern Ethiopia. Food Policy, 26(4), 351-365. http://dx.doi.org/10.1016/S0306-9192(01)00009-4

World Bank. (1994). Adjustment in Africa: Reforms, results and the road ahead. New York: Oxford University Press.

World Bank. (2000). Can Africa Claim the $21^{\text {st }}$ Century? Washington, DC: The World Bank.

\section{Copyrights}

Copyright for this article is retained by the author(s), with first publication rights granted to the journal.

This is an open-access article distributed under the terms and conditions of the Creative Commons Attribution license (http://creativecommons.org/licenses/by/3.0/). 